MARIA DĘBOWSKA - LUBLIN

\title{
KTO, KIEDY I GDZIE SPORZĄDZIL SPIS OSÓB Z PARAFII OSTRÓWKI (DIECEZJA LUCKA) ZAMORDOWANYCH 30 SIERPNIA 1943 R. PRZEZ NACJONALISTÓW UKRAIŃSKICH Z UKRAIŃSKIEJ POWSTAŃCZEJ ARMII
}

Historyk powinien być w pewnym sensie detektywem w przypadku, kiedy dostanie do rąk dokument niepodpisany, niedatowany, ale niezwykle przydatny do pokazania lub potwierdzenia pewnych faktów historycznych. Czasami, wbrew najlepszym chęciom i wiedzy, nie można $\mathrm{z}$ całą pewnością ustalić kiedy dokument został wytworzony, ani kto przyczynił się do jego powstania; wówczas pozostaje stwierdzenie prawdopodobieństwa. Nigdy nie wolno jednakże te problemy pozostawić nierozwiązane, a już szczególnie w przypadku, gdy przystępuje się do edycji takich materiałów archiwalnych.

W zasobie Archiwum Diecezji Łuckiej znajduje się jednostka archiwalna zatytułowana: „Spis alfabetyczny zamordowanych dn. 30 VIII 1943 w par. Ostrówki dekanatu lubomelskiego na Wołyniu". Ma ona wyjątkowe znaczenie ze względu na fakt, że jest najwcześniejszym spisem Polaków pomordowanych 30 sierpnia 1943 r., w czasie napadu bojówek Ukraińskiej Powstańczej Armii na dwie duże polskie wsie - Ostrówki i Wola Ostrowiecka. Jest wykazem najwcześniejszym, bo sporządzonym w przeciągu kilku miesięcy po napadzie. Ten niepełny, niestety, rejestr ofiar ludobójstwa w parafii Ostrówki uzupełniano - po latach - w oparciu o relacje żyjących jeszcze świadków zbrodni. W 2011 r. w Ostrówkach stanął, nieukończony dotychczas, pomnik upamiętniający ofiary ludobójstwa UPA. Na tablicach, które mają być umieszczone po bokach istniejącego już krzyża, z imienia i nazwiska mają być wymienieni wszyscy pomordowani w Ostrówkach i Woli Ostrowieckiej. Wspomniany „Spis” jest podstawą do sporządzenia listy ofiar ludobójstwa w parafii Ostrówki. Strona ukraińska podważa liczbę osób tam wymordowanych. Stąd szczególnie ważne jest ustalenie autorstwa tego dokumentu oraz czasu i miejsca jego powstania.

Lista osób przedstawiona w „Spisie” była już kilkakrotnie publikowana z koniecznymi późniejszymi uzupełnieniami - przez Leona Popka ${ }^{1}$, którego

${ }^{1}$ Wotyński Testament, oprac. L. Popek, T. Trusiuk, P. Wira, Z. Wira, Lublin 1997, s. 200-226; L. Popek, Cmentarz parafialny w Ostrówkach na Wolyniu, Lublin 2005, s. 168-192; tenże, Ostrówki. 
przodkowie pochodzili z parafii Ostrówki i ucierpieli w czasie napadu UPA 30 sierpnia 1943 r. Leon Popek pokusił się także o wytypowanie autora „Spisu”. Według niego, omawiany dokument jest ,przypuszczalnie autorstwa księdza kanonika Stefana Jastrzębskiego, dziekana lubomelskiego" ${ }^{2}$. Nie przeprowadził on jednak koniecznych badań dokumentu, ale przyjął a priori, że mógł go sporządzić jedynie dziekan dekanatu lubomelskiego, do którego to dekanatu należała parafia Ostrówki i dlatego tenże duchowny mógł się tą sprawą szczególnie interesować.

„Spis” doczekał się także edycji. Podjął się tego trudu Waldemar Witold Żurek $^{3}$. Wydawca zobowiązany był do sporządzenia opisu dokumentu przeznaczonego do publikacji oraz ustalenia kto, kiedy i gdzie go wykonał, jako że w te informacje „Spis” nie został zaopatrzony. Niestety tych ustaleń Wydawca nie poczynił. Informacje o publikowanym źródle zostały przez W.W. Żurka zaprezentowane w sposób następujący: „Autor [W.W. Żurek - M.D.] celowo nie dołączył tych szczegółów [uzupełniającego spisu pomordowanych osób, sporządzonego w oparciu o relacje żyjących świadków zbrodni - M.D.], aby przedstawić zestawienie pomordowanych mieszkańców parafii Ostrówki na podstawie spisu-dokumentu sporządzonego wkrótce po dokonanych mordach, a znajdującego się w Instytucie Archiwów, Bibliotek i Muzeów Kościelnych Katolickiego Uniwersytetu Lubelskiego Jana Pawła II w Lublinie przy ul. Chopina 29. Poniższy „Spis...” należy do części zespołu archiwalnego ${ }^{4}$ byłej diecezji łuckiej na Wołyniu, będącego w posiadaniu Instytutu ABMK KUL"5. W przypisie nr 25 (s. 137) Wydawca dokumentu dodał: ,,[...] autor [W.W. Żurek - M.D.] nie zastosował się do instrukcji wydawniczych źródeł aby zachować oryginalność i wagę drukowanego dokumentu-spisu". To jest wszystko, co Wydawca dokumentu miał o nim do powiedzenia.

Należy ubolewać, że W.W. Żurek nie ustalił autorstwa opublikowanego przez siebie źródła historycznego i jednoznacznie trzeba stwierdzić, że Leon Popek nie ma racji pisząc, że to ks. Stefan Jastrzębski, dziekan lubomelski postarał się o spisanie pomordowanych mieszkańców parafii Ostrówki.

Wyjaśnienie wszystkich nierozwiązanych spraw wiążących się ze wspomnianym dokumentem należy rozpoczać od opisu jego samego, gdyż tam przede wszystkim kryje się zagadka jego autorstwa. Jest to stustronicowy notes w kratki i w linie, w oprawie kartonowej, o wymiarach 16 x $10 \mathrm{~cm}$, dodatkowo zaopatrzony w papierową obwolutę. Na tejże papierowej obwolucie, w pierwszym segmencie, odnotowano informację: ,Spis zmarłych z ostrowieckiej parafii”, a w następnym: ,Z dekanatu lubomelskiego metryki spalone: Ostrówki, Pulemiec, Przewały". Na wierzchniej karcie oprawy notesu zostały umieszczone dwa tytuły. Jeden

Wotyńskie ludobójstwo, Warszawa 2011, s. 157-181.

${ }^{2}$ Wotyński Testament, s. 210, 227; Popek, Cmentarz parafialny w Ostrówkach na Wolyniu, s. 178, 192; tenże, Ostrówki. Wolyńskie ludobójstwo, s. 27.

${ }^{3}$ Zob. W.W. Żurek, Pomordowani 30 sierpnia 1943 r. w parafii Ostrówki na Wotyniu, „Rocznik Lubelskiego Towarzystwa Genealogicznego”, t. 3, Lublin 2011, s. 132-168; sam „Spis” jest opublikowany tamże jako aneks na stronach 138-166.

${ }^{4}$ Wydawca nie sprecyzował, który zespół archiwalny miał na myśli.

${ }^{5}$ Żurek, Pomordowani, s. 137. 
z nich - wpisany prawdopodobnie jako pierwszy w centralnej części miejsca przeznaczonego na tytuł - jest następujący: „Obligi mszalne”, a pod spodem: „Ks. W. Kryweńczyk". Drugi tytuł, umieszczony w wolnych miejscach (nad, pomiędzy i pod pierwszym) brzmi: „Spis zamordowanych w par. Ostrówki”. Dalszy ciąg drugiego tytułu: „Od 1 I 1944 r.” został wykreślony. W prawym, dolnym rogu wierzchniej karty oprawy widnieje informacja: „Rymacze”. Pełny tytuł dokumentu: „Spis alfabetyczny zamordowanych dn. 30 VIII 1943 w par. Ostrówki dekanatu lubomelskiego na Wołyniu" znajduje się na pierwszej stronie notesu.

Z powyższego wynika, że omawiany „Spis” został sporządzony w Rymaczach, w pierwszych miesiącach 1944 r. („Od 1 I 1944 r.”), przez właściciela notesu, a więc ks. Wiktora Kryweńczyka. Można przypuszczać, że na skutek próśb wnoszonych przez ocalałych z rzezi parafian ostrowieckich o odprawienie mszy za dusze pomordowanych, zrodziła się myśl spisania tragicznie zmarłych. Opisany notes przypuszczalnie miał pierwotnie posłużyć ks. Kryweńczykowi do wpisywania intencji mszalnych, które zobowiązał się odprawić. Widocznie nie dysponował czystym notatnikiem, czy zeszytem (takie przedmioty wówczas były bardzo trudne do zdobycia), więc zmienił przeznaczenie zatytułowanego już wcześniej notatnika. Dodatkowym argumentem przemawiającym za autorstwem ks. Wiktora Kryweńczyka jest dukt pisma. Porównano „Spis” z listami ks. Kryweńczyka do bpa Adolfa Piotra Szelążka. Potwierdziło to zgodność charakteru pisma autora „Spisu” z charakterem pisma listów ks. Kryweńczyka. Taki zabieg powtórzono w odniesieniu do ks. Jastrzębskiego. Pozwoliło to na zupełne wykluczenie dziekana lubomelskiego jako autora omawianego dokumentu.

Jak doszło do tego, że ks. Wiktor Kryweńczyk proboszcz parafii Przewały (w dekanacie lubomelskim) znalazł się w Rymaczach i stał się autorem „Spisu”?

Kiedy w ostatnich dniach sierpnia 1943 r. UPA organizowała napady na miejscowości w zachodnich powiatach Wołynia, duchowni - zazwyczaj wcześniej ostrzeżeni - przeważnie szukali bezpieczniejszego miejsca pobytu. Tak też zrobił ks. Wiktor Kryweńczyk, proboszcz parafii Przewały należącej do dekanatu lubomelskiego. Kiedy bojówki nacjonalistów ukraińskich zjawiły się 29 sierpnia (niedziela) $\mathrm{w}$ Przewałach nie zastały już tam proboszcza. Wymordowały parafian zgromadzonych w kościele ${ }^{6}$. Zaś proboszcz „,w nieznanych okolicznościach uciekł rano 29 sierpnia do Maciejowa (gm. Maciejów, pow. Kowel)"”. Wkrótce, wraz z ks. Franciszkiem Korwin-Milewskim proboszczem parafii Maciejów, ks. Kryweńczyk wyjechał za Bug. Obydwaj duchowni zatrzymali się na terenie diecezji lubelskiej ${ }^{8}$. Po kilku tygodniach wspomniani księża powrócili jednak do swojej diecezji. Ksiądz Milewski mógł pracować nadal w swojej parafii, natomiast parafia

${ }^{6}$ „Ukraińcy zaatakowali Polaków zgromadzonych w kościele - prawdopodobnie miejscowych oczekujących na mszę (nie wiedzieli, że ksiądz Wiktor Kryweńczyk wcześniej uciekł) i być może uciekinierów z mordowanych tego dnia osiedli polskich w okolicy”, W. Siemaszko, E. Siemaszko, Ludobójstwo dokonane przez nacjonalistów ukraińskich na ludności polskiej Wołynia 1939-1945, t. 1, Warszawa 2000, s. 879.

${ }^{7}$ Tamże, s. 880.

${ }^{8}$ Materiały do dziejów diecezji łuckiej. Relacje o stanie dekanatów i parafii 1941-1944, oprac. M. Dębowska, Biały Dunajec 2005, s. 119. 
ks. Kryweńczyka przestała istnieć. Parafianie zostali wymordowani lub rozproszeni, a kościół został spalony ${ }^{9}$. Na wezwanie ks. Stefana Jastrzębskiego dziekana dekanatu lubomelskiego, bezpośredniego zwierzchnika ks. Kryweńczyka, proboszcz przewalski ${ }^{10}$ rozpoczął więc w listopadzie 1943 r. posługiwanie w parafii Rymacze $^{11}$, gdyż tamtejszy proboszcz, ks. Stanisław Brajczewski, z obawy przed UPA, opuścił 30 sierpnia $1943 \mathrm{r}$. swoją parafię i już nie chciał tam powrócić na stałe $^{12}$. Samych Rymacz upowcy jednak nie zaatakowali ${ }^{13}$, a po sierpniowych napadach na okoliczne miejscowości została tam (Rymacze-Jagodzin) zorganizowana silna samoobrona ${ }^{14}$, która przetrwała do nadejścia armii sowieckiej w lipcu 1944 roku$^{15}$. Dopiero w tym czasie ks. Kryweńczyk opuścił Rymacze.

Z obawy przed upowcami mieszkańcy wielu miejscowości znajdujących się na terenie powiatu lubomelskiego uciekali do Jagodzina, gdzie była stacja kolejowa i posterunek niemiecki oraz do sąsiednich Rymacz, gdzie z kolei znajdował się kościół parafialny ${ }^{16}$. Według Władysława i Ewy Siemaszków, 30 sierpnia 1943 r. i w dniach następnych do Rymacz ,przybyła rzesza uciekinierów z osiedli polskich, w których ludność była mordowana: Jankowiec, Kątów [...], Ostrówek, Woli Ostrowieckiej (oba w gm. Huszcza), 31 sierpnia do wsi przybyli ocaleli z rzezi Ostrówek i Woli Ostrowieckiej. [...] Ludzie gromadzili się pod kościołem oraz w szkole" ${ }^{17}$. Rozmiary zbrodni w Ostrówkach i Woli Ostrowieckiej były tak olbrzymie, że ks. Kryweńczyk zdecydował się zebrać wśród uciekinierów informacje o pomordowanych i następnie sporządził ich spis, zachowując - w zasadzie - porządek alfabetyczny nazwisk.

\footnotetext{
${ }^{9}$ Tamże, s. 123.

${ }^{10}$ Ks. Wiktor Kryweńczyk używał pseudonimu konspiracyjnego: „Przewalski”.

${ }^{11}$ M. Dębowska, Kościół katolicki na Wotyniu w warunkach okupacji 1939-1945, Rzeszów 2008, s. 155.

${ }^{12}$ Materiały do dziejów diecezji łuckiej, s. 123.

13 „30 sierpnia 1943 r. wieś [Rymacze - M.D.] nie została zaatakowana przez UPA z tych samych powodów, z jakich nie napadnięto na wieś Jagodzin”, W. Siemaszko, E. Siemaszko, Ludobójstwo, t. 1, s. 498. „30 sierpnia 1943 r. Jagodzin (a także przylegające Rymacze) nie zostało zaatakowane przez UPA. Najprawdopodobniej UPA nie dysponowała dostatecznymi siłami, ażeby móc zapanować nad rozległym obszarem, a zmobilizowani chłopi z ukraińskich wsi po dokonaniu rzezi w kilku koloniach polskich rozpierzchli się rabować. Istotnym czynnikiem powstrzymującym od napadu była też stała obecność Niemców na stacji kolejowej”, tamże, s. 492.

14 „Powstałe kierownictwo samoobrony w Rymaczach przyjęło i realizowało plan obrony wsi: Rymacze, Jagodzin, Kupracze i Terebejki powołanymi tam placówkami w sile około plutonu, z komendantem Bazy w Rymaczach. Baza powoływała wszystkie pomocnicze służby łączności z placówkami, drużyną gospodarczą, służbą sanitarną, warsztatem rusznikarskim itp. Na komendanta Bazy powołano Czesława Różyńskiego (ppor. «Ogończyk»). Duchowo i organizacyjnie wspierał działalność samoobrony przybyły do parafii [Rymacze - M.D.] nowy proboszcz ks. Wiktor Kryweńczyk ps. «Przewalski»”, R. Markiewicz „Mohort”, Eksterminacja ludności polskiej przez OUNUPA w pow. Luboml, województwa wotyńskiego w latach 1943-1944, w: Wotyń i Małopolska Wschodnia 1943-1944, red. C. Partacz, B. Polak, W. Handke, Koszalin-Leszno 2004, s. 222.

${ }^{15}$ W. Siemaszko, E. Siemaszko, Ludobójstwo, s. 498-499.

${ }^{16}$ Zob. relacje zamieszczone w: Wolyński Testament; Popek, Cmentarz parafialny w Ostrówkach na Wołyniu; tenże, Ostrówki. Wotyńskie ludobójstwo.

${ }^{17}$ W. Siemaszko, E. Siemaszko, Ludobójstwo, s. 498.
} 